\title{
Beginselen van een goede verdediging
}

Citation for published version (APA):

Prakken, E. (1999). Beginselen van een goede verdediging. Gouda Quint. https://doi.org/10.26481/spe.19990507ep

Document status and date:

Published: 07/05/1999

DOI:

10.26481/spe.19990507ep

Document Version:

Publisher's PDF, also known as Version of record

\section{Please check the document version of this publication:}

- A submitted manuscript is the version of the article upon submission and before peer-review. There can be important differences between the submitted version and the official published version of record.

People interested in the research are advised to contact the author for the final version of the publication, or visit the DOI to the publisher's website.

- The final author version and the galley proof are versions of the publication after peer review.

- The final published version features the final layout of the paper including the volume, issue and page numbers.

Link to publication

\footnotetext{
General rights rights.

- You may freely distribute the URL identifying the publication in the public portal. please follow below link for the End User Agreement:

www.umlib.nl/taverne-license

Take down policy

If you believe that this document breaches copyright please contact us at:

repository@maastrichtuniversity.nl

providing details and we will investigate your claim.
}

Copyright and moral rights for the publications made accessible in the public portal are retained by the authors and/or other copyright owners and it is a condition of accessing publications that users recognise and abide by the legal requirements associated with these

- Users may download and print one copy of any publication from the public portal for the purpose of private study or research.

- You may not further distribute the material or use it for any profit-making activity or commercial gain

If the publication is distributed under the terms of Article $25 \mathrm{fa}$ of the Dutch Copyright Act, indicated by the "Taverne" license above, 
Beginselen van een goede verdediging 
Voor de Turks-Koerdische advocaten van

\author{
Abdullah Öcalan
}




\section{Beginselen van een goede verdediging}

Oratie uitgesproken op 7 mei 1999 bij de aanvaarding van het ambt van gewoon hoogleraar in het straf(proces)recht. aan de Universiteit Maastricht

door

Ties Prakken

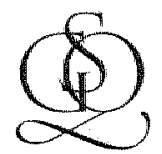

Gouda Quint

(S. Gouda Quint-D. Brouwer en Zoon)

Deventer 
Illustratie omslag: Aquarel "Het Proces" van Constant

Omslagontwerp: A. Birnie bNO

ISBN 9038707460

(0) 1999, E. Prakken

Alle rechten voorbehouden. Niets uit deze uitgave mag worden verveelvoudigd, opgeslagen in een geautomatiseerd gegevensbestand of openbaar gemaakt, in enige vorm of op enige wijze, hetzij elektronisch, mechanisch, door fotokopieën, opnamen of enig andere manier, zonder voorafgaande schriftelijke toestemming van de uitgever.

Voor zover het maken van kopieën uit deze uitgave is toegestaan op grond van artikel 16B Auteurswet 1912 jo. het Besluit van 20 juni 1974, Stb. 351, zoals gewijzigd bij het Besluit van 23 augustus 1985, Stb. 471 en artikel 17 Auteurswet 1912, dient men daarvoor wettelijk verschuldigde vergoedingen te voldoen aan de Stichting Reprorecht (Postbus 882, 1180 AW Amstelveen). Voor het overnemen van gedeelte(n) uit deze uitgave in bloemlezingen, readers en andere compilatiewerken (artikel 16 Auteurswet 1912) dient men zich tot de uitgever te wenden. 
Mijnheer de rector magnificus,

dames en heren.

\section{$1 \quad$ Inleiding}

Verdediging in strafzaken is niet vanzelfsprekend. Wat vanzelfsprekend is is dat de verdachte, die 'het' toch wel gedaan zal hebben, zonder al te veel omhaal wordt veroordeeld. Zijn verdediging heeft iets kunstmatigs.' De ruimte daartoe moet inderdaad kunstmatig gecreëerd worden, en in veel rechtsstelsels is dat in mindere of meerdere mate gebeurd, maar regelmatig worden we ermee geconfronteerd dat het gaat om een laagje beschaving dat niet al te dik is. Hoe stevig de verdediging in het zadel zit hangt af van een aantal factoren zoals de structuur van het strafproces waarbinnen zij moet functioneren, de heersende rechtscultuur daaromheen en de gangbare opvattingen over misdaad en de bestrijding daarvan. Andere factoren zoals de politieke en economische stabiliteit van het moment laat ik hier maar buiten beschouwing, maar de drie genoemde zal ik in deze oratie wat verder uitwerken en daaraan een poging verbinden om aan te geven waar de prioriteiten voor onderzoek op dit gebied zouden kunnen liggen, wat minimum garanties voor een behoorlijke verdediging zijn en langs welke wegen de randvoorwaarden voor een behoorlijke verdediging verbeterd zouden kunnen worden.

Peters wijst er op dat het toestaan van enige vrijheid van handelen van een verdachte in het kader wan het tegen hem aanhangige strafproces uberhaupt iets kunstmatigs heeft: A.A.G. Peters, Individuele wrijheid en de positie van verdachten in het strafproces, in: Recht als kritische discussie, Armhem Gouda Quint 1993, p. 79. 
In allerlei bepalingen in ons wetboek van strafvordering word de verdediging ondergeschikt gemakt aan de belangen van de opsporing. Zo heeft de raadsman op grond van artikel 50 , lid 1 het recht op vijje toegang tot zijn gedetineerde cliênt, zonder dat het onderzoek daardoor mag worden opgehouden, en mogen volgens artikel 30 de processtukken tijdelijk aan de verdediging worden onthouden wanneer het belang van het onderzoek dat vordert. Soms gaat de prioriteit van het onderzoek heel ver, zoals in artikel 50 lid 2, waarin de mogelijkheid wordt geschapen om de raadsman de toegang tot zijn gedetineerde clicnt te ontzeggen wanneer het vrij verkeer ertoe strekt dat de verdachte op de hoogte rakt van zaken waarvan hij in het belang van het onderzoek nog onkundig moet blijven. Het gat dus om en situatie waarin de raadsman er niet van wordt verdacht misbruik van zijn rechten te hebben gemaakt; dan kan het ook, maar dat is minder opzienbarend. Een zover gaande beperking van het wrije verkeer alleen omdat het onderzoek voorrang heeft, is voor zower mij bekend uniek in Europa, en het is zeer de vraag of deze bepaling te rijmen is met de garanties voor de verdediging zoals vastgelegd in artikel 6 van het Europees Verdrag voor de Rechten van de Mens (EVRM). De bepaling wordt gelukkig niet zoveel toegepast $t^{2}$ melar wat niet is kan komen en nieuwe vergaande achterstelling van de rechten van de verdediging bij het opsporingsbelang zijn in de maak zoals we zullen zien; de denkwijze achter deze achterstelling van de verdediging is bijzonder actueel. Dat de verdediging volgens de wet op de tweede plaats komt geldt vooral in het vooronderzoek. Tijdens het eindonderzoek wordt van de verdediging vervolgens verwacht dat zij over het vooronderzoek niet al te veel vragen stelt. Dat hangt ermee samen dat ons

2. Zie voor toepassingen van artikel 50 lid 2 buiten geval van misbruik: Rechtbank Alkmaar 30 april 1974, NJ 1975, 316, Rechtbank Maastricht 19 september 1975, NJ 1976, 195, Rechtbank Leeuwarden 15 mart 1978, NJ 1978,427, Rechtbank Arnhem 22 maart 1979, NJ 1979, 298 Rechitbank Breda 16 mei 1988, NJ 1988, 769, HR 11 oktober 1991 (civiele kamer), NJ 1993, 165, Rechtbank Amsterdam 8 februnri 1998, NJ 1998, 322. Het gaat steeds om (verschillend beoordeelde) gevallen watrin woor twee verdachten in eén zatak hetzij éen advocaat optrad, hetrij twee kantoorgenoten. 
strafproces traditioneel is gebaseerd op een groot vertrouwen in de integriteit van dat vooronderzoekals uitgevoerd door de politie onder werantwoordelijkheid van het openbaar ministerie. ${ }^{3}$ Zeker in het wooronderzoek, maar tot op grote hoogte ook in het eindonderzoek ter zitting, is de verdachte niet zozeer rechtssubject en procespartij dan wel voorwerp van onderzoek. Daar staat tegenover dat het bij ons vanouds de taak van de politie is on ook ontlastend bewijs te verzamelen en dat de officier van justitie altijd is gezien als magistrat, met een dienovereenkomstige verantwoordelijkheid voor de integriteit èn objectiviteit van het onderzoek. Wat ik zojuist heb opgesomd zijn een aantal prominente karaktertrekken van een modern inquisitoir strafproces, opgevat in een niet noodzakelijk negatieve zin, hoewel het woord inquisitoir bij velen die connotatie wel heeft. Een modern inquisitoir strafproces betekent een - in het Nederlandse geval zeer uitgesproken - paternalistisch proces, voor het goede verloop waarvan zowel officier van justitie als rechter verantwoordelijk zijn. Zij moeten daarom enerzijds zorgen "dat het recht $2 i j n$ loop heeft" maar aan de andere kant ook waken voor de bellangen van de verdachte. Dat impliceert dan weer dat de verdediging niet zo belangrijk is: er mag een raadsman zijn, maar het kan ook zonder. Is er wel een raadsman, dan moet hij zich rustig houden, in ieder geval op het punt van de bewijsvoering. Vragen over het door de politie uitgevoerde onderzoek naar de feiten zijn al gauw buiten de orde of chicaneus. Toch is de roemruchte IRT-affaire een affaire geworden doordat advocaten er niet alleen in slaagden de rechters danig te irriteren, maar uiteindelijk ook om twijfel te zaaien over de integriteit van het onderzoek en over de wettigheid van de daarbij gebruikte methodes, warvan de parlementaire enquêtecommissie zoals bekend heeft vastgesteld dat de meeste niet door de beugel konden. ${ }^{4}$

Deze karaktertrek van ons strafproces, afgezet tegen de situatie in Groot-Brittannië, is helder uiteengezet door Nico Jörg, Stewart Field en Chrisje Brants, Are Inquisilorialand Adversarial Systems Converging?, in: Phil Fennell, Christopher Harding, Nico Jörg en Bert Swart, Crintinal Justice in Europe; A Comparative Studly. Clarendon Press, Oxford 1995. Inzake opsporing, Eindrapport van de Parlementaire Enquêtecommissie onder voorzitterschap van van Traa, SDU 1996. 
Het is deze advocaten niet in dank afgenomen dat zij de vinger hebben gelegd op buitenwettelijke inkijkoperaties, idem observatiemethodeswaaronder begrepen hetplaatsen van afluisterapparatuur, burgerinfiltratie en nauwelijks gecontroleerde doorlating van drugs, om maar een paar te noemen van wat inmiddels eufemistisch "bijzondere opsporingsmethodes" heet."

Het is ook voor de positie van de verdediging van belang om zich te realiseren hoe het zover heeft kunnen komen met de politie, die bij ons toch vanouds zo integer was en zo objectief, en die zich in principe redelijk aan de wet hield. Dat komt voor een groot deel door de gewijzigde aanpak wan de misdaadbestrijding. Criminaliteit is en politieke issue van belang geworden. De behoefte aan een effectievere misdaadbestrijding, vooral gericht op de georganiseerde criminaliteit, heeft reorganisaties bij politie en openbaar ministerie tot gevolg gehad - die nog niet allemaal zijn afgerond - gericht op grotere doeltreffendheid van het onderzoek en grotere beleidscentralisatie bij het openbaar ministerie. ${ }^{6}$ De politie zowel als het openbaar ministerie zijn zich gaan specialiseren en niet iedereen. weet en begrijpt meer wat andere 'units' doen. Die "units' worden ook weer "afgerekend" om nog maar even bij het bureaucratische jargon te blijven, op hun successen bij het vangen van boeven. Dit alles heeft tot gevolg dat het vinden van de kortste weg naar belastend bewijs steeds belangrijker is geworden, ten koste van het vinden van een correcte weg naar de

De objectiviteit gebiedt overigens te zeggen dat de opgewekte irritatie ook kwam doordat er aanwijzingen waren dat de informatie over die onrechtmatige opsporing zelf op onrechtmatige wijze was verworven, door inbraken bij een officier van justitie en op een parket door persomen mogelijk uit de kring van de verdachten.

Met de recente reorganisatie van het openbaar ministerie die een veel sterkere hiërarchische structuur betekent, en dus een sterkere directe afhankelijkheid van de minister van justitie, is tevens het einde wan de zogenaamde magistratelijke officier van justitie afgekondigd. Het magistratelijke openbaar ministerie is symbolisch ten grave gedragen door het openilike en gemotiveerde ontslag wan de Amsterdamse procureur-general Mr A.G. Korvinus, die geen verantwoordelijkheid meer wil nemen voor beslissingen waarvoor zij de verantwoordelijkheid in werkelijkheid niet meer mag nemen. 
objectieve waarheid. Zeker bij de zo populaire bestrjiding van de 'georganiseerde criminaliteit' is er een grote druk om te scoren. Het gevolg: geheime opsporingsmethodes en deals met criminelen. In dit proces is de politie een stuk oncontroleerbaarder geworden. Een onbedoeld neveneffect van de deals met criminelen is echter dat de politie deze criminelen als min of meer volwaardige onderhandelingspartners accepteert: een deal sluit men met een rechtssubject, niet met een voorwerp van onderzoek. En wat is de ene crimineel minder dan de andere? Zo heeft onder meer door toedoen van een gewijzigde ananpak van de criminaliteitsbestrijding het verschijnsel onderhandelen zijn intree gedaan in het "gewone" strafrecht; in het fiscale- en economische strafrecht bestond het al langer. En zo raken ook advocaten gewend aan onderhandelen en nemen zij daartoe ook zelf waker het initiatief. Bovendien is de raadsman over het algemeen beter opgeleid dan vroeger en beter berekend voor zijn taak als volwaardig verdediger en tegenpartij van een steeds partijdiger politie en een steeds minder magistratelijk openbaar ministerie en heeft hij wia het Europees Verdrag voor de Rechten van de Mens (EVRM) een aantal instrumenten afgedwongen die het wetboek van strafvordering hem niet geeft. Het EVRM is, hoewel formeel 'neutraal' ten aanzien van een keuze tussen een inquisitoir- of een accusatoir proces, sterk beinvloed door de Angelsaksische accusatoire wijze van procederen in strafzaken, een procedure waarvan men blijkbaar na de Tweede Wereldoorlog het besef had dat deze meer bescherming had te bieden tegen hernieuwde misbruiken van het soort dat we in die tijd hadden leren verafschuwen, dan de alloude continentale gematigd inquisitoire processtijl. De integriteit van het inquisitoire proces is immers volledig afhankelijk van het in de overheid te stellen vertrouwen, en juist dat was niet meer vanzelfsprekend na de oorlog. Het opwerpen van barriëres tegen misbruiken als in het recente verleden ondervonden was het expliciete doel van het uit 1950 daterende verdrag. ${ }^{7}$

Het blijkt echter dat de strafrechtelijke cultuur die zich parallel aan het gematigde inquisitoire proces heeft ontwikkeld taaier is dan deze nieuwe inbreng vanuit de Raad van Europa. Nederlandse strafrechtjuristen zijn zo gewoon om de verdachte niet als vol waardig rechtssubject te zien, en rechters vinden het zo vanzelfsprekend dat zij in de eerste plaats

P. Van Dijk en G.J.H. van Hoof, De Etwropese Conwentie in Theorie en prakthk, derdedruk, Nijmegen, Ars Aequi Lubri, p. I e.v.. 
loyaal zijn aan het overheidsbelleid" dat zij de invloed van het verdrag weten te beperken of onschadelijk te maken ook in die gevallen waarin de regels op Straatsburgs voorschrift wel worden aangepast. Het strafrechtelijk systeem reageent op het verdrag als een lichaam op transplantatie wan vreemde organen: het probeert ze eerst af te stoten ${ }^{9}$ en als dat niet lukt worden ze geassimileerd. ${ }^{10}$ De invloed van het EVRM is daardoor beperkt, maar hij

Zie woor de typering van de continental Europese rechtspraak als primair een middel voor de doorwoering van overheidsbeleid Mirjan R. Damaska, The Faces of Justiceand Siate Authority. Yale University Press, New Haven and London 1986, o.a. p. 88. Damaska stelt deze functie van de continentale rechtspleging tegenover de conflictoplossende functie in het AngloAmerikaanse accusatoire proces.

Een voorbeeld van afstoten: twee arrestem van het EHRM warin geconstateerd werd dat Nederland artikel 6 van het verdrag had geschonden door gebruik te maken van anonieme getuigen a charge (EHRM 22 november 1989, A 166, N. 1990, 245 [Kostovski/ Nederland] en EHRM 23 april 1997, NJ 1997,635 [van Mechelen c.s./ Nederland]) hebben het gebruik van de anonieme getuige niet kunnen doen ophouden: rechter en wetgever werkiezen in deze langs de rand wan het toelaatbare te lopen en wanneer zij zich blijkens het tweede anonieme getuigenarrest toch nog aan de verkeerde kant van die rand blijken te bevinden, wordt er nog cen beetje biggesteld , maar er wordt blijkbaar niet aan gedacht het bij de uiteindelijke bewijswoering zonder anonieme getuigen te stellen zoals in de meeste landen om ons heen.

Een voorbeeld wan assimilatie laat de geschiedenis van de verdediging bij verstek zien: teen verdachte die niet ter zitting verscheen kon zich tot voor kort niet laten verdedigen door een raadsman, totdat het EHRM over die praktijk in de arresten Lala en Pelladoah (EHRM 22 september 1994, A 297-A, [Lala/Nederland], NJ 1994, 733 en A 297-B [Pelladoah/ Nederland]J zijn veto uitsprak als strijdig met de normen van een eerlijk proces. De praktijk van de rechtspraak paste zich aan en de verdachte die verstek liet gaan kon voortaan well door zijn raadsman verdedigd worden. Kort daarop reageerde de wetgever met de introductie van het nieuwe artikel $279 \mathrm{~Sv}$, dat van de raadsman van een niet werschijnende verdachte vraagt zich uit te spreken of hij bepaaldelijk gevolmachtigd is tot het voeren van de verdediging. Zo ja, dan geldt de procedure als te zijn gevoerd op tegenspraak, met alle gevolgen, onder meer voor de appeltermijn van dien. $Z$ o dient het aanpasser van de wet aan de eisen van het verdrag op het stuk van de rechten van de verdediging toch nog cen beleidsdoel: het terugdringen van het antal vonnissen dat niet onherroepelijk kan worden bij gebrek aan mogelijkheid van beteke- 
is er ontegenzeggelijk, al moet men altijd waakzaamblijven ten opzichte van argumentatie waarbij het verdrag wordt gebruikt om de rechten en mogelijkheden van de verdediging in te perken in plaats van uit te breiden ", een andere uiting van genoemde cultum waraan het positief denken in termen van grondrechten tamelijk vreemd is.

Dat brengt ons in een situatie waarin wij met een partijdig openbaar mimisterie, en politie die bovenal will scoren, een verdachte die meer dan voorheen mondig rechtssubject is en een verdediging die over enige middelen beschikt om het proces te beinvloeden, gaandeweg beland zijn in een strafproces dat meer accusatoire trekken vertoont en in ieder geval meer op tegenspraak verloopt. In het echte accusatoire proces, zoals we dat kennen in de Angelsaksische traditie, neemt echter ter nommering van het partijdige opsporingsonderzoek de notie 'fairness' een belangrijke plaats in ${ }^{12}$, maar in ons vooronderzoek is een dergelijke norm (nog) niet krachtig ontwikkeld. Wel heeft de Hoge Raad een poging gedaan $^{13}$, door aan het politieonderzoek de eis te stellen, op straffe van niet-ontwankelijkheid van het openbaar ministerie, dat het niet zodanig ernstige inbreuken op de beginselen van een behoorlijke procesorde mag maken dat daarmee doelbewust of met grote veronachtzaming van de belangen van de verdachte aan diens recht op een eerlijke behandeling van zijn zaak wordt tekort gedaan. Om tot dat resultaat te komen wordt op de verdediging

\section{ning.}

11 Enige voorbeelden: G. Knigge, in zijn preadvies voor de Nederlandse Juristenvereniging 1994, De strafivorderingin het geding, bepleit met een beroep op het noodzakelijke contradictoire karakter van de procedure de verplichte aanwezigheid van de verdachte in strafzaken van enige importantie. In de rechtspraak (bijv. Hof Amsterdam 1.5 april 1993, NJ 1993,478) wordt het EVRM wel gebruikt om het weigeren van getuigen onder meer te billijken met de noodzaak het proces binnen redelijke termijn af te ronden.

Zie over de toenadering tot op zekere hoogte van lnet Angelsaksische- en het Nederlandse strafproces Nico Jörg, Stewart Field en Chrisje Brants, Are Inquisitorial and Adversarial Systewas Converging?, in: Phil Fennell, Christopher Harding, Nico Jörg en Bert Swart, Criminal Justice in Europe; A Comparative Study, Clarendon Press, Oxford 1995. HR 19 december 1995, NJ 1996, 249, (Charles Z). 
echter wel een duvelse bewijlast gelegd. ${ }^{14}$ Tussen een uitspraak van de Hoge Raad en verankering in de cultuur bij politie en openbaar ministerie van een tegenover de verdachte "faire" opsporingspraktijk ligt echter vermoedelijk nog een lange weg te gaan.

Diezelfde ontwikkelingen bij politie en openbaar ministerie die in het strafproces een meer antagonistische opstelling tussen partijen tot gevolg hebben gehad en die dus mogelijk een structurele bijdrage tot een meer accusatoir proces zullen blijken te zijn hebben echter ook gezorgd voor een zwaarder inquisitoir element - en dan wèl in de negatieve betekenis van het woord - en met name voor een meer geheim onderzoek: in de bijna-wet Bijzondere Opsporings Bevoegdheden ${ }^{15}$ die het gevolg is van de parlementaire enquête over de opsporing, doet een nileww versehijnsel zijn intree in het strafprocesrecht: het getuigenverhoor buiten aanwezigheid van de verdachte en zijn raadsman wegens een zwatwegend opsporingsbelang. ${ }^{16}$ Bedoeld zijn verhoren van infiltranten en andere 'undercover" opererende personen die niet bekend willen worden bij de verdediging. Deze tegenstrijdige ontwikkelingen in het strafproces: meer op tegenspraak en meer geheim, leiden tot een hybride positie van de verdediging, die het al te makkelijk maakt om opportunistische standpunten in te nemen.

Inmiddels is het openbaar ministerie op deze grond een keer niet-ontwankelijk verklaard: Hof Den Haag 17 februari 1999, Nieuwsbrief Strafrecht 1999, 3, nr.47. Het betrof een zaak waarin een advocaat getapt was om bewijs tegen zijn cliënten en tegen de advocaat zelf als verdachte te vergaren.

Wetsontwerp 25 403; het betreft de bepalingen die naar verwachting als de artikelen 187 en $187 \mathrm{~d}$, lid 1 (b) binnenkort in het wetboek van strafvordering zullen worden opgenomen. Het enige andere voorbeeld van directe inbreuk op algemeen erkende verdedigingsrechten omdat de opsporing van de wetgever woorrang krijgt is gelegen in het eerder besproken artikel 50 lid 2 volgens hetwelk het vrij verkeer tussen de gedetineerde verdachte en zijn raadsman kan worden opgeschort, ook buiten her geval dat wan dat verkeer misbruik is gemaakt. 
Welke plats in de verschillende opvattingen over het strafproces aan de raadsman wordt toegekend, hangt vanzelfsprekend nauw samen met de positie die daarin aan de verdachte wordt toebedeeld. Historisch is goed traceerbaar hoe de verschillende stromingen die we de afgelopen 150 jaar in het strafrecht gehad hebben, het Klassieke strafrecht, de Moderne richting in verschillende varianten en het autoritaire strafrecht dat in de jaren " 30 opkwam, hun neerslag hadden op de plaats die voor de verdediging darin werd ingeruimd. ${ }^{17}$ Onder de strafzaken waarin schendingen van fundamentele maatschappelijke watrden aan de orde zijn - en dat zijn de strafzaken waarin verdediging tegelijkertijd het meest noodzakelijk èn het meest kwetsbaar is - onderscheidt Peters ${ }^{18}$ twee historisch-en actueel voorkomende procestypes. In de eerste plaats het bij ons zo sterk ontwikkelde paterrialistische proces waarin de verdachte vooral geacht wordt problemen te hebben waarvoor door redelijk goedwillende justitiële autoriteiten oplossingen worden aangedragen; ondat een dergelijk proces nauwelijks op tegenspraak is georganiseerd, leent het zich niet woor een sterke verdediging. Daartegenoverplaatst hij het inquisitoriale proces waarin de verdachte, vaak een bedreigende politieke tegenstander van de heersende macht, letterlijk en/of figuurlijk als persoon vernietigd wordt, de advocaat meestal met de verdachte wordt meegecriminaliseerd en de verdediging om die reden geen eerlijke kans krijgt. Het nu in Turkije gevoerde proces tegen Koerdenleider Öcalan, in de Turkse media stelselmatig 'de babymoordenaar" genoemd, is er een duidelijk voorbeeld van. Toen mijn kantoorgenoten en ik niet tot Turkije werden toegelaten waar we de belangen van onze cliënt willen beschermen, werd daarvoor als reden opgegeven dat wij sympathisanten van het terrorisme

Daarover Han Janse de Jonge en Ties Prakken, Politieke verdediging: een rechisstatelijk dilemma, NJB 1978, p. 325 e.v..

A.A.G. Peters, Individuele vrijheid en de positie van de verdachten in her strafproces, in: J.Th.J. van den Berg et al. (red.), Praesidium Libertatis: opstellen over het thema vrijheid en recht, uitgegeven ter gelegenheid van het 400-jarig bestaan der Rijksuniversiteit Leiden, Deventer, KLuwer 1975; ook opgenomen in: Recht als kritische discussie, een selectie uit het werk van A.A.G. Peters, Arnhem: Gouda Quint 1993, p. 79 e.k.. 
waren die onder het mom advocaat te zijn de openbare orde kwamen verstoren. Een volstrekt klassiek verwit in een even klassieke mar bedenkelijke situatie. In Nederland komt deze vorm van proces gelukktg niet in zuivere vorm voor" ${ }^{19}$, al zijn er steeds meer trekken yan dit type proces te herkennen bij de berechting van de veronderstelde leiders van criminele organisaties waaraan het openbaar ministerie de "oorlog" heeft verklaard.

Tegenover de processen waarvan de uilkomst wordt bepaald zonder dat de verdachte zelf of zijn raadsman darop serieus invloed kunnen uitoefenen stelt Peters het ideaal van "procedure" ${ }_{\text {" }}$ en kunstmatige opbouw van een tegensprekelijke vorm waarin ruimte wordt gecreeerd voor de verdachte zelf, die als rechtssubject serieus wordt genomen en wiens belangen in principe legitiem zijn en de moeite wan het verdedigen waard; waarin de verdediging een eerlijke kans krijgt het resultaat van de procedure daadwerkelijk te beinvloeden. Dit is het ideaal van de accusatoire procedure waarin grondrechten centraal staan; in Nederland is deze procedure niet historisch verankerd. Dat blijkt onder meer uit de manier waarop door rechterlijke macht en wetgever wordt omgesprongen met het EVRM. De "heersende leer' in Nederland neemt kennis van het EVRM en de bijbehorende rechtspraak en probeert de schade ervan aan het vertrouwde inquisitoire proces te beperken. Het enige wat aanslaat in de adversaire structuur is de mogelijkheid die het biedt om de volle verantwoordelijkheid voor het realiseren van processuele rechten bij de verdedi-

Wel had het proces in eerste aanleg tegen de hoofdverdachte van de in naam van RaRa uitgevoerde aanslagen zo'n tien jaar geleden daar een aantal kenmerken van. Zo werd deze verdachte door de politie voorgehouden dat 'ze nu alles van hem wisten en hem nooit meer met rust zouden laten'. De stijl van verhoren door de politie was dienowereenkomstig en deze zijn in een door de verdachte aangespannen kort geding (opgenomen in HR 23 november 1990, NJ 1991, 184, waarbij de Hoge Raad beslist dat de weg wan de strafraadkamer gekozen had moeten worden en zich verder over de inhoudelijke merites van de zaak niet uitspreekt) ook ontechtmatig verklaard. De politie maakte ook de verdediging verdacht. In eerste aanleg werd het proces op cen manier geleid die tot op grote hoogte recht doet aan de beschrijving door Peters van het inquisitoriaal proces, in hoger beroep werd veel goedgemaakt. 
ging te leggen. ${ }^{20}$ Uit niets blijkt dat men zich door de nieuwe mogelijkheden die het verdrag biedt laat inspireren.

\section{Verdediging en de kijk op misdaad}

Visie op verdediging heeft ook te maken met visie op misdaad. In de media kunnen we regelmatig lezen dat het ministerie van justitie de "oorlog" aan de drugshandel heeft verklaard, dat "de strijd wordt aangebonden" tegen de georganiseerde criminaliteit, tegen zinloos geweld en noem maar op.

Het is bij ons vooral de criminoloog Nagel $^{21}$ geweest die erop heeft gewezen dat daar waar oorlog gevoerd wordt weinig plaats is voor het recht, en dat dit soort martiale terminologie in het kader van de misdaadbestrijding dan ook weinig goeds belooft voor het juridisch karakter van de rechtsstrijd die daaruit voortvloeit. ${ }^{22}$ Oorlog betekent vernietigen, niet debatteren, terwijl het debat als vorm van conflictbeslechting nu juist typerend

Vooral L.C.M. Meijers benadrukt in zijn Groningse oratie Verdrag en strafproces; Gedachten over een methode van werken, Tjeenk Willink Zwolle 1993, dat het verdrag de volle verantwoordelijkheid voor het bevredigend verloop wan de procedure bij de verdediging legt. In zijn Leidse inaugurele rede van 1956, Het Strafrecht en de Onmens, in bewerkte vorm nieuw uitgegeven in: W.H. Nagel, Het betrekkelijkevan criminaliteit, Criminologische cahiers deell 1, Samson, Alphen aan de Rijn 1976.

Dat ook oorlogen in overdrachtelijke zin zich slecht verdragen met het recht is een notie die indertijd ten grondslag heeft gelegen aan de rechtshulpbeweging van de zestiger jaren in de Verenigde Staten; het programma ter bestrijding van de structurele armoede dat door L.B. Johnson was ontworpen droeg de naam 'War on Poverty', waarop juristen het plan inbrachten om naast economische en sociale maatregelen ook rechtshulp ter beschikking van arme wijken te stellen, juist om aan de autoritaire kanten wan de 'war' een tegenwicht te bieden door de betrokkenen de gelegenheid te geven zelf voor hun rechten op te komen. Edgar S. Cahn en Jean $\mathrm{C}$. Cahn, The War on poverty: a Civilian Perspective, The Yale Law Journal, Vol. 73, p. 1317 e.w. (1964). De geschiedenis van deze beweging is beschreven in Ties Prakken, Rechtshulp en Juridies Activisme, Nijmegen Ars Aequi Libri 1985, p. 29 e.v.. 
is voor het recht. ${ }^{23}$ In zijn criminologie betrok hij dan ook terecht behalve het gedrag en de verantwoordelijkheid van wetsovertreders die van de vervolgende staatsorganen, van de media, het publiek en alle andere betrokkenen die in relatie tot misdaad beslissingen nemen. "Er leeft (...) een verkeerd ventje in de mens, een Oude Adam, een rotzakje. Dat is de fascist-avant-la-lettre" ${ }^{*}$ schreef Nagel onder zijn literaire pseudoniem J.B. Charles ${ }^{24}$, en dat sloeg op delinquenten èn op overheidsdienaren, èn op iedereen die verkeerde dingen laat gebewren zonder in te grijpen. ${ }^{25}$ Voor Nagel hadden criminologie en strafrechtspleging van alles te maken met bestrijding van fascisme ün al zijn verschijningsvormen. In die zin lopen zijn strevingen opvallend parallel met die van de opstellers wan het EVRM.

Een verdachte die als mens verantwoordelijk gesteld kan worden woor wat hij heeft gedaan omdat hil geacht wordt dat in een mate van persoonlijke wrijheid te hebben gedaan, heeft ook de principiete vrijheid om als subject van rechten in de procedure te participeren en daarin keuzes te maken en zich naar behoren te verdedigen.

De visies op strafrecht en criminologie van Peters en Nagel vormen de uitgangspunten warop een effectieve verdediging theoretisch kan worden gegrondwest. Het juridische oordeel dat verdediging er niet alleen moet zijn maar dat deze ook effectief moet zijn, kwam onlangs nog eens op pregnante wijze van het Europese Hof voor de Rechten van de Mens, dat op 4 maart j.I. in de Ocalanzaak een unieke interimmaatregel tegen Turkije

In de speltheoretische benadering van conflictanalyse wordt het debat als de typisch juridische yorm van conflictbeslechting gezien, zo bijvoorbeeld door Anatol Rappoport, Fights, Games and Debates, vijfde druk, The University of Michigan Press, Ann Arbor 1974.

J.B. Charles, Van het kleme koude front, de Bezige Bij, Ansterdam 1962, p. 300.

Dit citaat wordt ook gebruikt door A.A.G. Peters in zijn necrologie voor Nagel, In Memoriam Professor Mr W.H. Nagel, in: Tijdschrift voor Criminologie 25 (1983), p. 161 e.v, ook opgenomen onder de titel W.H. Nagel: de criminoloog en het strafrecht in A.A.G. Peters, Recht als Kritische Discussie, Gouda Quint, Arnhem 1993, p. 161 e.v.. Peters rekent terecht ook de romans van Nagel tot aijn criminologisch werk. 
heeft genomen door van dit land garanties te vragen dat deze verdachte effectieve- en inhoudelijk ongecontroleerde contacten kan hebben met zijn advocaten. ${ }^{26}$

Uit deze uitspraak valt niet alleen af te leiden dat het Europese Hof gealarmeerd is over de wijze waarop Turkije voornemens lijkt ziju staatsvijand nummer ến to berech$\operatorname{ten}^{27}$, er blijkt ook uit dat het hof in een adequate verdediging de enige mogelijkheid ziet om van een eerlijk proces - voor zover daar gegeven de omstandigheden uberhaupt sprake van kan zijn - nog iets te redden, wat klaarblijkelijk de reden was om deze eisen aan Turkije vooraf te stellen. Helaas vergeefs, want Turkije negeert de interimmaatregel.

De tekst van de maatregel is niet gepubliceerd, maar een persbericht hierover is te vinden op de Website van het EHRM: http:/www dhcour.coe.fr. Dat het recht op verdediging ex artikel 6, lid 3 (c) 'practical and effective" hoort te zijn is al eerder uitgemaakt (EHRM 13 mei 1980 , A 37 [Artico], EHRM 9 april 1984, A 76 [Goddi], EHRM 28 nowember 1991, A 220 [S/ Zwitserland], in welke laatste zaak het ook gaat om het vrije verkeer tussen een verdachte en zijn raadsman. Wat nieuw is in de beslissing ten aanzien van Ocalan is dat de effectiviteit, mede tegen de achtergrond van de bedreigde doodstraf en de berechting door een staatsveiligm heidshof waarvan door het EHRM al eerder was uitgemaakt dat het wegens de aanwezigheid van een militair daarin niet kon gelden als een "impartial tribunal', blijkbaar voor het lof een zo nijpend probleem was dat het reden was woor een interimmaatregel. De noodzaak van de interimmaatregel wordt door het EHRM beargumenteerd met de mogelijkheid dat de doodstraf wordt opgelegd enerzijds en anderzijds met de berechting door cen staatsweiligheidsrechtbank waarvan het EHRM in twee eerdere zaken al heeft uitgemaakt dat deze niet voldoet aan de criteria voor een onpartijdige rechtbank zoals vereist volgens artikel 6 EVRM, omdat wan deze rechtbanken een militair deel uitmaakt. Inmiddels heeft Turkije de militair uit de staatsveiligheidstechtbanken verwijderd, zonder dat overigens de in de oude samenstelling met militair genomen beslissingen ten nadele van de verdediging zijn teruggedraaid over opnieuw overwogen. Inmiddels is aan Ocalan bij vonnis van 29 juni 1.999 de doodstraf opgelegd. 
Dat Turkije in de Ocalanzak de rechten van de verdediging met voeten treedt zal in West-Europa nauwelijks betwist worden. Ook in West-Europa en ook in Nederland is er echter reden tot waakzamheid met betrekking tot de positie van de verdediging, al zijn geen gemaskercle militairen aanwezig bij de gesprekken tussen gedetineerden en hun raadsman. Het zijn subtielere mechanismen die het recht op een effectieve verdediging hier bedreigen.

Over de plats van de verdediging in het Nederlandse strafproces is relatief heel weinig geschreven ${ }^{2}$ en er is ook weinig rechtspraak over. Dat gebrek aan belangstelling is toe te schrijven aan de vrij marginale positie die de verdediging altijd gehad heeft, ook in de juridische doctrine. Nu daarin toch wel verandering lijkt te komen, wordt die juridische positie van belang. In het wetboek staat dat de verdachte een raadsman mag kiezen (artt. 38 en 39) of er een toegevoegd kan krijgen (artt. 40-48) en dat die raadsman net als de verdachte zelf recht heeft op kennisneming van de stukken (art. 51). Voor het onderzoek ter terechtzitting is bepaald dat alle rechten van de verdachte ook aan de raadsman toekomen (art. 331) en verder zijn de zogenaamde privileges van de raadsman

Een chronologische geordende greep uit de Nederlandse publicaties waarin de positie van de verdediging als zodanig onderwerp van beschouwing is: H. Janse de Jonge en Ties Prakken, Politieke verdediging een rechtsstatelijkdilemma, NJB 1978, p. 325 e.v., P.H. Bakker Schut, Ties Prakken en Th. de Roos, Politiek protest in de rechtszaal, elementen van een politieke verdedigingin openbare orde zaken, Recht en Kritiek 1984, p. 33 e.w. Ties Prakken, Verdediging: hoezoe equality of arns? NJB 1990 p. 887 e.v., Th.A. de Roos, Verdediging van belangen. het belang van de verdediging, oratie Maastricht, Gouda Quint, Arnhem 1991 , T.N.B.M. Spronken, Rechten van de verdediging, in: Precaire Waarden, Liber Amicorum voor Prof. mr. A.A.G. Peters, Gouda Quint, Arnhem 1994, p. 107 e.v., G.P.M.F. Mols en T.N.B.M. Spronken, Aanval op de verdediging: Bespiegelingen over advocaten en criminaliteiten de verdediging in strafakten, Advacatenblad 1996, p. 506 e.v., T.N.B.M. Spronken, Spiegel van de ziel van de rechtsorde. Ower verdediging en waarhedswinding in: G.P.M.F. Mols en M. Wladimiroff, Homo Advocatus, Spong bundel, SDU Den Haag 1998, p. 191 e.w.. 
geregeld, waaronder het recht op vrij verkeer met de gedetineerde verdachte (art. 50) en het bij de professionele geheimhoudingsplicht behorend verschoningstecht (att. 218) worden gerekend. De geheimhouding wordt verder in het wetboek ondersteund met bepalingen ter beperking van de mogelijkheid tot inbeslagneming (art. 98) en van het aftappen van telecommunicatie (art. $125 \mathrm{~h}$ ). Wat nadrukkelijk niet in het wetboek stat is hoe er verdedigd moet worden. Dat zou ook in strijd zijn met de vereiste onafhankelijk heid wan de verdediging. Op grond van deze summiere wettelijke regeling kan ervan uit worden gegaan dat de raadsman een van de verdachte afgeleide positie heeft en dat daamaast de verdediging enige privileges heeft die het werken mogelijk moeten maken en die de aan de beroepsuitoefening van een advocaat inherente vertrouwelijkheid van het contact met de cliënt beschermen voor de situatie dat die cliënt een verdachte is tegen wie een strafvorderlijk onderzoek loopt en voor de situatie dat die cliênt gedetineerd is. De raadsman heeft dus buiten die privileges niet meer rechten dan zijn cliènt heeft en moet die ook niet willen hebben. ${ }^{29}$

Een bekende en actuele vraag bij de beantwoording waarvan de visie op strafproces en misdaadbestrijding centraal staat, maar vaak nuet geëxpliciteerd wordt, is die naar de al dan niet publieke functie van de raadsman. Tot voor kort ging men er bij ons over het

Soms probeert de rechter een bepaald recht wel aan de raadsman toe te kennen maar niet aan de verdachte zelf. $Z_{0}$ is in HR 7 mei 1996, NJ 1996, 687 beslist dat van stukken die geen processtukken zijn maar waarvan de verdediging mag kennisnemen ter onderbouwing van een gevoerd verweer, het onder omstandigheden voldoende is wanneer de raadsman (i.c. raadsivrouw) er kennis van neemt en niet de verdachte zelf, wanneer de belangen van de opsporing dat nodig maken. Het ging om fotoboeken die nog voor toekomstige opsporing gebruikt zouden kunnen worden. De raadsvrouw die onder die omstandigheden inzage weigerde kon er volgens de Hoge Raad niet met vrucht een beroep op doen dat de verdediging geen behoorlijke inzage had gehad. Een dagelijks voorkomend geval van een recht dat aan de tuadsman maar niet aan de verdachte wordt gegeven is het recht om bij verhoren bij de rechter-commitssaris aanwezig te zijn. 
algemeen van uit dat de raadsman geen publieke functie lheeft" ${ }^{30}$ geen 'officer of the court" is: aangezien de verdachte geen functionaris is in het strafproces is de raadsman dat ook niet, zo werd vrij algemeen aangenomen, want diens rechten zijn afgeleid van die van de verdachte, die 'dominus litis' is. Dat betekent dat de raadsman slechts gebonden is aan de grenzen van het tuchtrecht, van zijn geweten en van het wetboek van strafvordering, dat een aan de opsporing ondergeschikte positie aangeeft maar geen normen stelt waaraan de verdediging zich in het belang van de strafvordering heeft te houden.

Met betrekking tot inhoudelijke verplichtingen van de raadsman tegenover de rechtsorde heeft de Hoge Raad ${ }^{3 !}$ een keer uitgemaakt dat de raadsman weliswaar niet verplicht was het adres van zijn cliènt aan het parket bekend te maken, maar dat hij zelf zijn cliënt op de hoogte had moeten stellen van de zittingsdag (wat het openbaar ministerie bij: gebrek aan adres niet kon), ook nu dat kennelijk niet in het belang van de verdachte was. Aldus spaarde de Hoge Raad kool en geit nog enigszins door van de raadsman niet meteen te eisen dat hij bij de tegenpartij te biecht gaat en dus zijn geheimhoudingsplicht schendt, maar wel inhoudelijke eisen aan zijn werk te stellen met het oog op de belangen van de rechtsgang, ook wanneer die niet samenwallen met de belangen van zijn cliẻnt.

Intussen is een discussie èn een juridische strijd gaande over de vraag of de raadsman dan misschien toch gebonden is aan beginselen van een behoorlijke procesorde zoals die voor het openbaar ministerie gelden en of bepaalde verdedigingshandelingen misschien

Zie ook Corstens, Het Nederlands Strafprocesrecht, tweede druk, Gouda Quint 1995, p. 88, die zich terecht op het standpunt stelt dat de raadsman geen orgaan van de strafrechtspleging is, maar dat hij toch een rechtsstatelijke meerwaarde heeft als tegenwicht tegen- en controleur van politie en openbaar ministerie. Overigens is dat vroeger, met name in de periode dat het strafrechtelijk denken autoritaire trekken begon aan te nemen in de jaren " 30 en " 40 , wel anders geweest. Zie daarvoor Han Janse de Jonge en Ties Prakken, Politiekeverdediging:een rechtsstatelijkdilewima, NJB 1978 , p. 325 e.v.

HR 29 juni 1993, NJ 1993, 717. 
misbruik van procesrecht opleveren. Cleiren ${ }^{32}$ heeft zich in een artikel over dat onderwerp heel woorzichtig uitgelaten en is tot de slotsom gekomen dat in principe de verdediging, aan wie in ons strafproces niet de positie van gelijlkwaardige partij toekomt, niet gebonden is an de voor de publieke partij in het strafproces geldende beginselen van cen behoorlijke procesorde. Gebruik van processuele bevoegdheden door de werdediging kan volgens haar daarom nooit tot misbruik worden bestempeld op de grond dat ze voor een ander doel worden gebruikt dan waarvoor ze zouden zijn gegeven. Zij maakt daarbij aarzelend een uitzondering voor extreme gevallen wanneer het optreden van de radsman volstrekt niet meer past in- of apert in strijd is met de strekking van de bevoegdheid en het belang van de verdachte niet meer een rechtens te beschermen belang kan worden genoemd. Een ruime mate van vaagheid kan aan dit criterium niet worden ontzegd, maar duidelijk is in ieder geval dat zij de deur voor misbruik van procesrecht door de verdediging niet meer dan op een heel klein kiertje heeft willen zetten en dat zij in ieder geval heeft willen voorkomen dat aan de verdediging wordt opgelegd zich te scharen achter de publieke doelen van de strafvordering als zodanig of achter de doelen wan een concrete officier van justitie in een concrete strafzaak. ${ }^{33}$

Zo'n 'extreem geval' deed zich voor toen door een raadsman cassatieberoep was ingesteld tegen een beslissing die geheel volgens de wensen van de verdediging was, maar door welk cassatieberoep in dat geval werd verhinderd dat de hoofdzaak voorlopig

32 C.P.M. Cleiren, Een grensoverschrijdendeverdachte? in: Grensoverschrijdend strafrecht. Een bundel opstellen geschreven door de medewerkers van de afdeling straf(proces)recht, Rijksuniversiteit Leiden, Gouda Quint, Arnhem 1990, p. 141 e.v..

't Hart, in een noot onder HR 12 februari 1991, NJ 1991, 527 onderschrijft de verwerping door Cleiren van aan de verdediging te stellen eisen omtrent het innemen van een bepaalde proceshouding. Hij haakt hierbij aan an een toen in de media gevoerde discussie waarin de: roep om het inperken van de verdediging voor het eerst sinds lange tijj weer luid gehoord werd, en gebruikt zijn bespiegelingen over de positie van de verdediging om kritische kanttekeningen te plaatsen bij de vergoelijkende wijze waarop de Hoge Raad schendingen vain processuele beginselen door de opsporende- en vervolgende organern slechts sanctioneert wanneer de verdediging aantoont daardoor concrete schade te hebben geleden. 
inhoudelijk zou worden behundeld. Het hof ${ }^{34}$ vond dit misbruik van procesrecht maar de Hoge Raad ${ }^{35}$ was van oordeel dat de verdachte geen rechtens te beschermen belang had bij het cassaticberoep. Anders dan het hof gebruikt de Hoge Raad het woord misbruik van procesrecht niet, maar houdt zich aan het door Cleiren aangereikte criterium van het rechtens te beschermen belang, een terminologie die in leder geval het uitgangspunt respecteert dat de raadsman er is om voor de belangen van zijn cliënt op te komen en niet voor die van de vervolgende staatsorganen. ${ }^{36}$ Natuurlikk kunnen de criteria in elkaar overgaan wanneer belangen van de verdediging die contrair zijn aan de belangen van de vervolging te gauw worden bestempeld als rechtens niet te respecteren belangen, maar vooralsnog houd ik het ervoor dat de Hoge Raad met het gebruik van deze terminologie bedoeld heeft zich min of meer terughoudend uit te laten.

3 Hof Amsterdam 15 april 1993, NJ 1993, 478.

\$5 HR 22 februari 1994, NJ 1994, 306. Van Veen gaat in zijn noot onder dat arrest niet in op de principiele kwestie van misbruik van procesrecht door de verdediging, maar komt met de praktische suggestie om de wet in die zin te wijzigen dat de mogelijkheid van hoger beroep tegen een beschikking warin men volledig gelijk heeft gekregen, wordt uitgesloten zoals hoger beroep tegen een vrijspraak is uitgesloten. De kwestie van misbruik van procesrecht wordt well aan de orde gestell en alls bruikbaar concept verworpen, door Mols in een redactioneel van de Nieuwsbrief Strafrecht 1999, p. 82, waarin hij het Hof ook bekritiseert om diens nevenoverweging dat het door de raadsman gevoerde vertragingsbeleid in strijid zou komen met het recht wan de verdachte op berechting binnen redelijke termijn en met het belang van de gemeenschap dat strafzaken tijdig worden berecht. Het is immers de verdediging die zelf kan uitmaken of van het recht op berechting binnen redelijke termijn afstand kan worden gedaan.

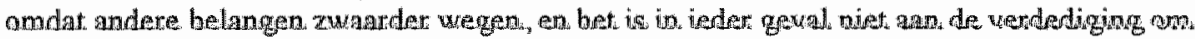
de belangen van de gemeenschap in zijn overwegingen bij het instellen van rechtsmiddelen te betrekken. 
Helaas theeft de Hoge Raad een andere uitspraak van het Amsterdamse Hof ${ }^{\text {? }}$, walar bij dit het te laat oproepen van een getuige in strijd had geoordeeld met de "ook voor de verdediging geldende beginselen van een behoorlijke procesorde', in stand gelaten. ${ }^{3 \%}$

Vertegenwoordigers van het openbaar ministerie, die zich soms ergeren an het optreden van raadslieden, hebben dit arrest aangegrepen als argument voor de stelling dat de verdediging gebonden is aan beginselen van een behoorlijke procesorde, dan wel in sommige gevallen misbruik van procesrecht maakt. Tijdens een onlangs gehouden conferentie over de polarisatie in de rechtszaal, georganiseerd door de bij de strafrechtspleging betrokken beroepsorganisaties, hield de plaatsvervangende Amsterdamse procureur-generaal Myjer een pleidooi voor binding van de raadsman aan beginselen van een behoorlijke strafprocesorde onder toejuiching van het laatst genoemde arrest, wagrin tot zijn genoegen nu eindelijk de verdediging aan banden werd gelegd. Hij gaat zelfs nog wat verder en wil dat de verdediging in wat tegenwoordig 'megazaken' heten rekening houdt met de beperkte zittingscapaciteit van de rechterlijke macht opdat ook nog tijd overblijft voor de gewone zaken. ${ }^{39}$ De advocaat als coöperatieve ondersteuner van het beleid van het ministerie wan justitie om de rechterlijke macht onderbezet te houden!

In de tijdens genoemde conferentie gevoerde discussie over deze kwestie merkte de adwocaat $M$. Wladimiroff op dat de werdediging zich naturlijk alleen te houden heeft aan beginselen van een goede verdediging. Ik heb dat in die context gelanceerde begrip tot titel van mijn oratie gemakkt, overigens met toestemming van de auteur. Maar met een pakkende term is het leerstuk - want dat is het aan het worden - over de vraag natar de al dan niet publiekrechtelijke functie van de verdediging natuurlijk niet uitgewerkt. Dat is het ook niet met de gespierde taal van Myjer op die conferentie.

Intussen zit het parket niet stil en in de nu tegen de Surinaamse adviseur van staat Bouterse lopende strafzaak wegens drugshandel heeft de Haagse advocaat-general de processuele opstelling van de verdediging, die een verzoek had ingediend om de zaak door

Hof Amsterdam 25 april 1996, NJCM 21 (1997) p. 21.

HR 8 april 1997, NJCM $23(1998)$, p. 14.

B.E.P. Myjer, Over de grenzen van behoorlijkheid: een OM-pleidooi woor een saatere reahts. strijd. Een aanzet tot discussie, Trema 1999, p. 76 e.v.. 
de rechtbank in Rotterdam werder te laten berechten omdat er meer aanrakingspunten met dat artondissement zouden zijn, als misbruik van procesrecht aangemerkt, onder andere wegens het late tijdstip van het verzoek, waaraan de wet van rechtswege schorsing van de vervolging verbindt. (De verdediging heeft kennelijk meer belang bij de aan het rechtsmachtgeschil verbonden schorsing, waarmee waarschijnlijk een verstekbehandeling kan worden voorkomen, dan bij verplatsing van het geding naar Rotterdam.)

Bij de behandeling van het schorsingsverzoek bij het Haagse hof halde de advocaatgeneraal $^{\text {at }}$ aldaar ongekend wit in de richting van de raadsman en vroeg hij het hof behalve het verzoek af te wijzen ook om vast te stellen dat de advocaat zich aan misbruik van procesrecht had schuldig gemaakt. Hij stelde daartoe, onder instemmende aanhaling van het eerder genoemde artikel wan Cleiren (die precies het tegendeel heeft beweerd): "De rechter heeft zo bezien de bevoegdheid de in de wet geformuleerde rechten en bevoegdheden van de verdachte zo te interpreteren dat diens aanspraken erop zijn beperkt tot de strekking die de wetgever eraan heeft willen geven.' Hij gaf vervolgens een opsomming van de zijns inziens geldende criteria voor misbruik van processuele bevoegdheden door de verdediging, waaronder het niet in acht nemen van het belang van de gemeenschap bij een woortvarende berechting van strafzaken!

Helaas is de hiërarchisering van het openbaar ministerie inmiddels zover voortgeschreden dat er niet van mag worden uitgegaan dat het hier een uitglijder van een individuele ambtenaar geldt. ${ }^{\text {al }}$ In tegendeel: onze minister van justitie heeft zelf in een inter-

De zaak is nog niet gepubliceerd.

Gelukkig heeft het hof in Den Haag, dat hierop een beslissing moest nemen het hoofd koel gehouden en het verzoek van de verdediging afgewezen (met een redenering in de trant van: "eetn redelijke wetsuitleg brengt mee dat...", dus zo vamzelfsprekend was het ook weer niet) en is op de kwestie van het misbruik van procesrecht niet ingegaan, "reeds omdat het verzoek niet op de wet is gebaseerd". Wel heeft de Haagse rechtbank de behandeling van de zaak gewoon voortgezet hoewel de wet aan het aanhangige rechtsmachtgeschil wan rechtswege schorsing wan de vervolging verbindt. De rechtbank gaf ter gelegenheid van haar beslissing om door to procederen een verklaring af die weer uitvoerig rept van misbruik van processuele bevoegdheden door de verdediging. (opgenomen in NJB 1999, p. 619 e.v.). 
view ${ }^{42}$ laten weten dat advocaten in strafzaken regelmatig misbruik maken van procesw recht door onredelijk veel geturgen op te roepen. Het is duidelijk uit welke hoek de wind waait.

Hoe zit het nu met de beginselen van een goede procesorde waaraan de verdediging zou zijn gehouden? Het leerstuk van de beginselen van een goede procesorde wordt ook wel gezien als de Nederlandse "vertaling" van de rechten van de verdediging zoals die in artikel 6 EVRM centraal staan. In ieder geval kan wolgens de Hoge Raad pas van schending van die beginselen sprake zijn wanneer de belangen van de verdediging concreet geschaad zijn, waarmee belangrijke principes van het strafproces, zoals de interne openbaarheid en het beginsel dat verklaringen van een verdachte in vrijheid moeten zijn afgelegd, als het ware geprivatiseerd worden to belangen van de verdachte en zijn onttrokken aan de publieke verantwoordelijkheid van de overheidsorganen die in het strafproces een rol spelen. Dat heeft zichtbare gevolgen wanneer die belangrijke beginselen zijn geschonden op een manier die de verdachte niet in zijn particuliere belangen heeft geschaad, bijwoorbeeld omdat hij aan de op hem uitgeoefende druk weerstand heeft geboden. ${ }^{43}$ De Hoge Raad gaat zover dat hij heeft beslist dat zonder vaststelling dat de verdediging in haar belangen is geschaad, de constatering dat beginselen van een behoorlijke procesorde zijn geschonden onbegrijpelijk is. ${ }^{44}$

Advocatenblad $1999 \mathrm{nr}$ 1. Het bestuur van de Nederlandse Vereniging van Strafrechtadvocaten heeft de minister om opheldering gevraagd, maar die was bij het ter perse gaan van deze oratie nog niet ontvangen.

Over dit probleem is geschreven door T.M. Schalken, Schending van wettelijkeprocesvoorschriften en het redelijke belang wan de verdachte: een redelijk criterium? Enkele inleidende opmerkingen, in: T.M Schalken en E.J.Hofstee (red.): In zijn verdediging geschaad; Over vormverzuimen en het belang van de verdachte, Gouda Quint, Arnhem 1989. Schalken benadrukt hier vooral het publiekrechtelijke karakter van de strafprocessuele normen en verzet zich om die reden tegen het criterium dat alleen een sanctie op overtreding van normen wordt gesteld wanneer het redelijk belang van de verdachte geschonden is.

HR 29 maart 1994, NJ 1994, 577. 
Maar afgezien vall de beperking van de rechten van de verdediging tot private belangen van de verdachte, die van de beginselenrechtspraak thet gewolg is, gebeurt er met die rechten nog iets wanneer ze tot beginselen van een goede procesorde worden omgevormd. Dergelijke beginselen zijn immers in wezen een kwaliteit van het strafproces, dat er rechtsstatelijker, netter uitziet wanneer daarin een mate van onschendbaarheid rond de verdachte wordt gerespecteerd, wanneer de verdachte als mens wordt behandeld. Maar rechten van de verdediging zijn meer dan een sympathieke eigenschap wan het strafproces, daaraan is ook, in termen van het Europese Hof, een mate van effectiviteit verbonden. Het is juist die effectiviteit die verloren dreigt te gaan bij de vertaling van rechten van de verdediging in beginselen van een goede procesorde.

De nu in de hitte van de strijd geopperde mogelijkheid om ook de verdediging te binden aan beginselen van een goede procesorde is rijkelijk bizar tegen het licht van het door de Hoge Raad gestelde criterium dat beginselen pas aan de orde zijn in geval van concrete schade aan de rechten van de verdediging, en het gebruik van de beginselenterminologie zegt dan ook vooral iets over de verhouding tussen emoties en rationaliteit in de discussice.

Behalve een logische inconsistentie zit er ook een ideologische frictie in de gedachtengang waarbij de beginselen van toepassing worden verklaard op de verdediging: enerzijds kunnen beginselen van een behoorlijke procesorde alleen geschonden worden wanneer de verdachte concreet in zijn belangen is geschaad, waarmee de verdedigingsrechten tot private rechten worden gereduceerd, maar anderzijds worden tegelijkertijd aan de verdediging in de persoon van de raadsman eisen gesteld die alleen aan publieke functionarissen gesteld kunnen worden, namelijk dat bevoegdhe den slechts gebruikt mogen worden voor het doel waarvoor zij gegeven zijn. De verdedigingsrechten worden dus beperkt tot private rechten, de werdedigingsplichten uitgebreid tot de plichten van een publiekrechtelijke functionaris. Dat is precies wat je ziet gebeuren met de verdediging in controversiele politieke strafprocessen in landen waar het rechtsstatelijk denken niet erg ontwikkeld is: de raadsman wordt tegelijkertijd met zijn cliënt vereenzelvigd en dus meegecriminaliseerd, èn gebonden aan allerlei regels die zijn bevoegdheden binden aan dat wat politiek aanvaardbaar wordt geacht. Gezien deze serieuze inconsistenties is het onbegrijpelijk dat de Hoge Raad zelf deze terminologie voor ongewenst geoordeeld gedrag 
van de verdediging inmiddels lijkt te laten passeren. Die onbegrijpelijkheid is alleen tot aanvatdbare proporties terug te brengen wanneer wordt aangenomen dat de Hoge Raad bij schending van beginselen van een goede procesorde door de verdediging alleen de "verkeersregels" van het strafproces op het oog heeft en verder geen waardeoordelen over de opstelling van de verdediging bedoelt te laten passeren. De casusposities warrin het tot nu toe speelde geven aan die veronderstelling steun. ${ }^{4 *}$ Een dergelijke beperkte uitleg zou in overeenstemming zijn mel de moeite die de Hoge Raad kennelijk gedaan heeft om in het vermelde "extreme geval' de terminologie van misbruik van procestecht te vermijden. Wanneer de Hoge Raad inderdaad bedoelt aan de verdediging alleen de eis te stellen dat zij rechts houdt in het verkeer, zou hij overigens ter beperking van misverstand beter alleen kunnen spreken van procesorde zonder 'beginselen'. De beginselenjurisprudentie van de Hoge Raad zou dan consistent kunnen blijven en een gevarlijke notie als toetsing van het optreden van de verdediging aan de beginselen van een goede procesorde zou buiten de deur gehouden kunnen worden. Dan blijft er duidelijkheid over bestaan dat de processuele positie van de verdachte niet kan worden ingeperkt tot éen die functioneel moet zijn binnen de officiele doelstellingen van het strafproces.

Iets dergelijks geldt woor de term 'misbruik van procesrecht', die nog ernstiger klinkt dan schending van de beginselen van een goede procesorde, maar waarbij het soms gaat om dezelfde soort bezwaren tegen het optreden van de verdediging, zoals bijvoorbeeld door de Haagse procureur-generaal in de zaak Bouterse geformuleerd. Terwijl de binding van de raadsman aan publieke doelen de implicatie is van het toepasselijk verklaren van de beginselen van een behoorlijk procesrecht op het doen en laten van de verdediging; verwijst het gebruik van de term 'misbruik van procesrecht' eerder naar het criminaliseren van de raadsman, zoals de laatste jaren soms ook letterlijk is gebeurd, achteraf bijna altijd zonder succes, door raadslieden als verdachten aan te merken in de strafzaken tegen hun

HR 6 april 1999, NJCM 24 (1999), p. 476 en HR 16 maart 1999, nr. 110.162, niet gepubliceerd; in beide gevallen ging het om raadslieden die niet een keer maar twee keer reageerden op de conclusie van het openbaar ministerie bij de Hoge Raad. De Hoge Rad neemt van die tweede 'Borgersteactié' geen kennis ondat die in strijd met de beginselen van een goede procesorde zijin ingediend. 
clienten. Het effect wan beide mechanismen is hetzelfde. Ongeacht het taalgebruik zijn dergelijke verwijten an de verdediging onterecht. Wanneer immers de verdediging rechten heeft moet zij daar ook op een strategische manier gebruik van kunnen maken ter bevordering van de belangen van de verdachte zoals de verdediging die zelf ziet, en die hoewen niet te passen in het officiele strafworderlijke beleid.

Bij dit alles moet ook niet worden vergeten dat in het strafproces het gebraik van juridische instrumenten voor een ander doel dan waarvoor ze zijn gegeven soms een goed middel tot rechtsontwikkeling is. Zonder aanvaarding van een dergelijk 'oneigenlijk' gebruik van bevoegdheden in de rechtsprak zou bijwoorbeeld de hele jurisprudentie rond niet-ontvankelijkheid van het openbaar ministerie op inhoudelijke gronden in strijd zijn met beginselen van een behoorlijke procesorde, want het instituut van niet-ontvankelijkheid is klaarblijkelijk door de wetgever niet bedoeld om tot een inhoudelijke beoordeling wan het gedrag van politie en openbaar ministerie te komen. Advocaten hebben desondanks niet-ontvankelijkheidsverwerengevoerd op inhoudelijke gronden, en zij zijn daarin door de rechtspraak (en inmiddels door de wetgever) gevolgd.

Over wenselijkheid, effectiviteit en ethiek van verdedigingsstrategieën valt ruimschoots te discussiẻren, en dat moet in de kring van de strafrechtadvocatuur misschien meer gebeuren. Maar misbruik kan door de verdediging alleen gemaakt worden van haar privileges: wanneer een raadsman zich schuldig maakt aan drugs- en wapensmokkel in het huis van bewaring is dat misbruik van het vrij verkeer en wanneer het advocatenkantoor een safe-lhouse wordt is dat misbruik van geheimhoudingsplicht en verschoningsrecht.

Zowel de vereenzelviging van raadslieden met hun cliëten als de inperking van hun speelluimte tot binnen de doeleinden wan de vervolging, passen in de tradities van het inquisitoire strafproces in de beladen zin van het woord, waartegen het EVRM een buffer moest zijn. Precies om die reden is de huidige tendens tot criminaliseren en conformeren in strijd met het EVRM, niet alleen in Turkije. Het stemt niet tot optimisme dat bij de eerste tekenen van een iets meer adversair strafproces, dat nog lang niet accusatoir kan

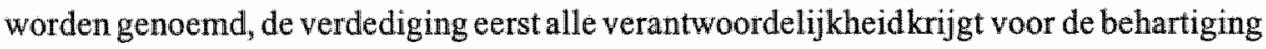
van de belangen van de verdachte om verwolgens, wanneer zij die verantwoordelijkheid begint te nemen, te worden gediskwalificeerd wegens misbruik van procestecht of schending van de beginselen van een behoorlijke procesorde. De meest welwillende interpretatie 
is die van rolverwarring in een onduidelijke overgangsfase. Meer wijst er echter op dat het om een algemene verharding gaat. Het werschijnsel is namelijk Europees, al liggen de accenten per land wat anders: in Dwitsland zitten advocaten in de gevangenis wegens heling omdat zij zich hebben laten betalen uit gelden wasvan de herkomst onvoldoende was gecheckten Engelse advocaten worstelen met dezelfde consequenties van witwasbepa. lingen. In Frankrijk is in liet kader van een grote fraudezaak onlangs huiszoeking gedaan bij een adwocaat om achter de verblijplaats van zijin woortvluchtige cliènt te komen en in Turkije zijn de advocaten van Öcalan ter zitting door de politie in elkaar geslageft.

\section{Wat zijn beginselen van een goede verdediging?}

Als de verdediging, indien serieus genomen, dus niet gehouden is aan beginselen van een goede procesorde en geen misbruik van procesrecht kan maken, wat zijn dan beginselen van een goede verdediging?

Uitgangspunt voor zulke beginselen moet in ieder geval zijn een verdachte die als volwaardig rechtssubject aan de procedure deelneemt en die gezien zijn positie van vervolgde bescherming behoeft van zijn grondrechten. Binnen die uitgangspunten moet de verdediging effectief kunnen zijn in die zin dat zij in staat is de resultaten van het proces te beînvloeden en tenminste haar subjectieve kant van de waarheid daarin in te brengen.

Daarmee maak ik al duidelijk dat de discussie over beginselen van een goede verdediging niet in de eerste plaats en zeker niet alleen zou moeten gaan over wat de verdediging allemaal niet mag. Belangrijker is wat verdediging moet mogen en moet kumen, en waar de interventiegrenzen voor politie en openbaar ministerie liggen. Dat is geen exclusief Nederlands- maar een mondiaal- en Europees probleem, waarbij niet alleen gekeken moet worden naar wat zich in de verschillende Europese landen afzonderlijk afspeelt. De Europeanisering van het strafrecht die door het Verdrag van Amsterdam mogelijk is geworden, zal ook geen dode letter blijven: er ligt onder de fraaie nam 'Corpus Juris' 
al een woorstel woor Europese strafbaarstelling en berechting van "eurofraude: "H6 fraude met gelden van de Europese Unie, dat alle kemmerken vertoont van een proefballon voor verdere inhoudelijke europeanisering van het strafrecht en het strafprocesrecht. Tegenover de dararin voorgestelde European Public Prosecutor (EPP) staan minimale garanties voor de verdediging, wier rechten genivelleerd dreigen te gaan worden op het laagste Europese peil.

Hard nodig is daarom een Europees statut voor de verdediging waarin elementaire processuele bevoegdheden worden gegarandeerd, waaronder het recht om bij alle verhoren van de verdachte en van getugen aanwezig te zijn en het onverkorte recht op toegang tot alle relevante stukken vanaf het moment van hum bestaan. Daarin zouden ook de klassieke privileges verder moeten worden uitgewerkt en van praktische garanties moeten worden voorzien. De principièle onafhankelijkheid van de raadsman ten opzichte van de staat en zijn beleid zou daarin ook moeten worden vastgelegd. Daarnaast zouden in zo 'n statuut gedragsethische regels kunnen worden opgenomen, waaronder een catalogus van wat de verdediging zoal moet doen ten behoeve van zijn cliënt behalve hem ter zitting bij te staan: regelmatig contact onderhouden, zorgvuldig zijn wensen inventariseren en een

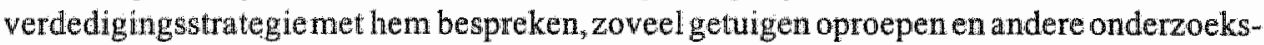
handelingen verzoeken als bimnen die strategie nodig is, processuele initiatieven nemen

Mireille Delmas-Marty, Corpus Juris; houdende strafbepalingen ter bescherming wan de financièelebelangen van de Europese Unie. Nederlandse bewerking met voorwoord van Chris van den Wyngaert, Intersentia Rechtswetenschappen Antwerpen - Groningen 1998. Het betreft een Europees wetgewingsproject op verzoek van de Europese Unie door een groep Europese strafrechtgeleerden uitgewerkt. Het leidende principe is een Europese strafbaarstelling en een berechting in principe volgens nationaal procesrecht, maar met Europese aanpassingen. Het project voorziet in een Europees parket voor deze delicten, dat beschikt over speciale opsporingsbevoegdheden en dwangmiddelen. Voor wat betreft de rechten wan de verdediging valt te vrezen dat met name het geheime vooronderzoek en de gebrekkige en late toegang tot de processtukken een verzwakking wan de positie van de verdediging zullen betekenen. Zie in kritische zin ook Taru Spronken, Corpus Juris en de rechten van de werdediging, redactioneel Nieuwsbrief Strafrecht 1999, p. 122 e.v.. 
die in het belang van de cliënt kumnen zujn, zeer alert zijn op (dreigende) schendingen van mensenrechten en daar actie op ondernemen en op alle denkbare geoorloofde manieren de visie van de cliënt met betrekking tot diens strafrechtelijke situatie in de ruimste zin naar buiten toe uitdragen zonder dat de raadsman zich hoeft te laten leiden door angst voor repercussies wan wat voor aard dan ook. ${ }^{47}$ En bovenal: binnen het kader wan wat wettelijk geoorloofd is altijd loyaal zijn aan de belangen van zijn client.

\section{Wat betekent dit alles voor het onderzoek?}

De onzekere-en van weinig inzicht in de rol van de verdediging getuigende discussie over baar positie, is tegelijkertijd een schreeuw om onderzoek. Gezien de verschuivingen die plaatsvinden in het strafproces, deels door structurele factoren ten gevolge wan een ingrijpend gewijzigde cultuur van opsporing en vervolging, deels onder invloed van het EVRM, is het noodzakelijk zich daarbij te bezinnen op de beroepsrol van de verdediger tegen de achtergrond van het strafproces waarin de verdediging moet functioneren. Het ligt daarbij voor de hand om rechtsvergelijkend te werk te gaan, en dan wel op de manier als door Damaska ${ }^{48}$ bepleit, die recht doet aan verschillen in types strafproces in samenhang met verschillen in de organisatie van de staatsmacht. Een dergelijk vergelijkend onderzoek kan inzicht geven in de grondslagen van de positie van de verdediging binnen verschillende concepties wan strafproces. Zo'n onderzoek, dat in Maastricht deels in uitwoering is en waartoe deels het initiatief al is genomen, zou op een of andere manier

47 Deze minimum garanties voor een behoorlijke verdediging zijn al opgenomen in de Basic Principles on the Role of Lawyers, angenomen op het Crime Congress van de Verenigde Naties van 1990 in Havana. Dit is een buitengewoon bruikbaar docunent ondat het zowel het recht van de verdachte op bijstand van een raadsman in een eerlijk proces stipuleert, als een aantal rechten wan de advocaten, zoals het recht op een goede opleiding, op bescherming door de overheid, op vrijheid var meningsuiting en andere rechten, en ook de plichten van een advocaat tegenover zijn cliènt. M.R. Damaska, o.c. in noot 8. 
betrokken moeten worden bij het grondslagenonderzoekten behoeve wan een hercodificatie van het wetboek van strafvordering dat in Groningen en Tilburg ter hand is genomen.

Ook vragen de beginselen van een goede verdediging waarvan ik de grove contouren heb geschetst om onderzoek naar die processuele rechten die als randvoorwaarden voor een effectieve verdediging werken, zoals toegang van advocaten tot gedetineerden in het eerste stadium van het proces en hun bevoegdheden in het vooronderzoek, de interne openbaarheid van het strafproces en de controle op de opsporing. Tenslotte is onderzoek nodig naar middelen ter versterking van de verdediging, die noodzakelijk is wanneer de tendens naar een meer adversair strafproces, accusatoir of niet, zich doorzet, om de voorwaarden aan te geven waaronder de verdediging die nieuwe taken aankan.

\section{Tot slot}

Ik heb voor vanmiddag over mijn onderwerp gezegd wat ik te zeggen heb. Dat de strafrechtjuristen onder $u$ na vanmiddag nog niet van mij af zijn wat betreft de verdediging zal wel duidelijk zijn. Volgens goede academische traditie is het dan nu tijd voor een paar persoonlijke opmerkingen.

Strafrecht heb ik geleerd van Toon Peters, al was ik, toen ik in Utrecht wetenschappelijk medewerkster werd, al hoog en breed jurist en advocaat. Behalve leermeester en vriend was hij ook leeftijdgenoot en daarom had hij er vanmiddag bij moeten zijn. Het is helaas anders gelopen en dat spijt mij meer dan ik hier zeggen kan.

Ik kan niet zeggen dat Willem Nagel mijn criminologische leermeester is, want ik weet te weinig van criminologie orm voor die summiere kennis naar een leermeester te kunnen verwijzen. Een onderscheid, niet wetenschappelijk verantwoord, dat ik pleeg aan te brengen in de criminologische geschriften die mij onder ogen komen, is of ik er voor het strafrecht iets aan heb of niet in de zin dat ik er meer door van het strafrecht begrijp. Naar dat criterium scoren de geschriften van Nagell hoog. In momenten van twijfel en onzekerheid over het nut van het bezig zijn met strafrecht, hoef ik maar aan zijn werk te denken en ik weet het weer: het draait allemaal om het bestrijden van dat verkeerde ventje in ons. Nagel was een generatie ouder dan ik en in zoverre is het beter te accepteren dat 
hij er niet bij is vandaag. Hij is er echter toch een klein beetje bij, want ik draag zijo toga. Ik kan u niet zeggen hoe geroerd ik was toen mij berichten bereikten dat Heleen Naggel een bestemming zocht voor de toga van haar man en op advies van Loek Hulsman mij daarvoor op het oog had. Ik ben er trots op, dank je wel. Daamee is dan tevens verklaard waarom $\mathrm{k}$ mij vandaag heb uitgedost als vreemde eend in de bijt.

Dezelfde functie als het lezen van het werk van Nagel, namelijk weer te achterhalen waar het uiteindelijk om draait in het strafrecht, hebben woor mij mijn periodieke reisjes. naar Turkije wanneer daar weer een of ander proces is dat die naam nauwelijks verdient tegen mensen die meer vrijheid willen of die mensen verdedigen die dat willen. Die lessen in bewustwording heb ik allemaal ondernomen in het rume kader van mijn werk voor ons advocatenkantoor in Amsterdam. Dat is een goed kantoor omdat er ruimte is voor dit soort aktiviteiten en omdat iedereen die ruimte op een of andere manier benut. Dat ik nu nog maar heel gedeeltelijk aan het kantoor ben verbonden èn dat ik Turkije niet meer in mag, wordt goedgemaakt door de wetenschap dat niet alleen de sectie strafrecht op kantoor de laatste tijd belangrijk versterkt is, maar ook dat de kwestie Turkije meer dan ooit op de kantooragenda staat, in welk verband in ieder geval de naam van Britta Böhler moet vallen.

Dan Maastricht: aangeland in een fase van mijn bestaan waarin ik enige gevoeligheid begin te ontwikkelen voor leeftijdsdiscriminatie, wat mij vroeger altijd een schijnprobleem leek, wil ik het college van bestuur zeggen dat ik bijzonder wardeer dat u het met mij heeft aangedurfd ondanks de betrekkelijk korte periode die ik heb om hier iets van de grond te krijgen.

De juridische faculteit moet blij met mij zijn want ik ben goed voor de statistieken: Nederland staat op de wereldlijst waarop van alle landen het relatieve aantal vrouwelijke hoogleraren wordt bijgehouden op de tweede plaats wan onder: alleen Botswana scoort slechter. Binnen Nederland scoort ongetwijfeld de juridische faculteit Maastricht het slechtst, want ik ben er de eerste en enige vrouwelijke hoogleraar. U moet zich schamen en beterschap beloven.

De vakgroep strafrecht (het woord capaciteitsgroep krijg ik niet over mijn lippen: alsof het alleen om burocratisch te verdelen menskracht gaat en niet on vakgenoten en collega's die dagelijks met elkaar te maken hebben en die inhoudelijk met hetzelfde vak 
bezig zijn) wil ik zeggen dat ik blj ben dat het enthousiasme en de solidariteit waarvan het bestaan mij tijdens mijn sollicitatie verzekerd was er ook werkelijk blijken te zijn en dat we dus echt een wakgroep zijn. Van de stafleden noem ik alleen Taru Spronken bij naam, collega op het gebied van de verdediging, bij wie het altijd gaat om vruchtbare samenwerking, nooit om concurrentie.

Gerard Mols en Grat van den Heuvel, mijn collega hoogleraren in de vakgroep ken ik ook langer dan vandaag: min makkers uit Utrecht geven mij hier het gevoel dat ik terug ben van weggeweest, meer dan dat ik een nieuw avontuur ben begonnen. Daardoor is het avorturur dat het ook is gelukkig geen eenzaam avontuur.

De studenten wil ik voorhouden dat de juridische opleiding gezien als deel van de opvoeding een aaneensehakeling is van identificatieprocessen. Identificatie met de rol van de verdediging is is daarbij de meest uitclagende keuze die gemaakt kan worden, al past identificatie met de rol van de rechter traditioneel meer in onze cultuur. Dat mag desnoods ook, als u maar goed voor ogen houdt dat het in elke positie in het strafrecht uiteindelijk om de mensenrechten gaat.

Tot slot Wendela en Heleen: mijn eerste wetenschappelijke publicaties kwamen tot stand ondanks jullie en wellicht ook ten koste van jullie. Daarna bleef het lange tijd schipperen met de aandacht en waren er natuurlijk ook verwijten daarover van jullie. Nu hebben jullie ondubbelzinnig postitief gereageerd toen ma op haar oude dag tot hoogleraar in het diepe zuiden werd benoemd. In sommige opzichten wordt het lewen met het verstrijken van de jaren simpeler. 